\title{
Inhibitive effect of an alcoholic extract of a seaweed Sargassum Muticum in controlling corrosion of mild steel in $0.5 \mathrm{~N} \mathrm{HCl}$
}

\author{
V. Jeslina, ${ }^{1}$ S.J. Kirubavathy, ${ }^{1}$ A. Al-Hashem, ${ }^{2}$ S. Rajendran, ${ }^{3,4}{ }^{\circ *} *$ \\ C. Lacnjevac ${ }^{5}$ and R.M. Joany ${ }^{6}$
}

${ }^{I} P G$ and Research Department of Chemistry, PSGR Krishnammal College for Women, Coimbatore - 641 004, India

${ }^{2}$ Petroleum Research Centre, Kuwait Institute for Scientific Research, Kuwait

${ }^{3} P G$ Department of Chemistry, Corrosion Research Centre St. Antony's College of Arts and Sciences for Women Thamaraipadi, Dindigul - 624005, Tamil Nadu, India

${ }^{4}$ Adjunct Professor, Pondicherry University, Puducherry, India

${ }^{5}$ University of Belgrade, Faculty of Agriculture, Belgrade, Serbia

${ }^{6}$ Department of ECE, Sathyabama University, Jeppiaar Nagar, Rajiv Gandhi Road, Chennai, Tamil Nadu - 600119, India

*E-mail: susairajendran@gmail.com

\begin{abstract}
The inhibitive effect of an alcoholic extract of a seaweed, namely, Sargassum Muticum, in controlling corrosion of mild steel in $0.5 \mathrm{~N} \mathrm{HCl}$ has been evaluated by weight loss method (immersion period 1 day) and electrochemical techniques such as polarization study and AC impedance spectra. The protective film has been investigated by AFM and Vickers Hardness test. Weight loss method reveals that $500 \mathrm{ppm}$ of inhibitor offers $99 \%$ inhibition efficiency to mild steel immersed in $0.5 \mathrm{~N} \mathrm{HCl}$. The adsorption of inhibitor molecules on the metal surface follows Langmuir adsorption isotherm. The $R^{2}$ value is very high, 0.998 . Polarization study reveals that the corrosion potential is slightly shifted to anodic side. It is inferred that the inhibitor solution functions as mixed type corrosion inhibitor. In the presence of the inhibitor, the linear polarization resistance $(L P R)$ increases and the corrosion current decreases. Because of the Blanket effect (formation of a protective film on the metal surface blocking the anodic sites and cathodic), electron transfer from the metal to the bulk of the solution is blocked. AC impedance spectra confirm the formation of a protective film on the metal surface. As the inhibitor concentration increases, the $R_{\mathrm{ct}}$ value increases and the double layer capacitance $\left(C_{\mathrm{dl}}\right)$ decreases, the impedance increases and the phase angle increases due to the blocking effect on the metal surface. It is found to be a monolayer of protective film. The Vickers hardness of the inhibited metal surface is lower than that of polished metal but higher than that of corroded surface. The average roughness, RMS roughness and maximum peak-to-valley height of inhibited metal surface are lower than those of corroded metal surface but higher than those of polished metal surface. The outcome of the study may be used in pickling industry where $\mathrm{HCl}$ is used to remove rust and at the same time metal surface is protected.
\end{abstract}


Keywords: corrosion inhibition, green inhibition, acid medium, Sargassum Muticum, Vickers hardness, AFM, adsorption isotherm, electrochemical studies.

\section{Introduction}

The rust in iron is removed by immersing the corroded metal in acid medium such as hydrochloric acid. This is known as pickling. During this process the metal may undergo corrosion. To prevent this corrosion many inhibitors have been used.

Rbaa et al. have used 8-hydroxyquinoline based chitosan derived carbohydrate polymer as biodegradable and sustainable acid corrosion inhibitor for mild steel. They have used computational analysis also in their study. Electrochemical studies and SEM have been used [1]. The corrosion inhibition of 3,3-dithiodipropionic acid on Q235 steel in sulphuric acid medium has been investigated by Guo et al. Polarisation study SEM have been used in the study [2]. Soltani et al. have studied the inhibitory effect of Pistacia khinjuk aerial part extract for carbon steel corrosion in sulfuric acid and hydrochloric acid solutions. Weight loss method and electrochemical studies have been used [3]. Thermodynamic and kinetic insights into the role of amino acids in improving the adhesion of iota-carrageenan as a natural corrosion inhibitor to the aluminum surface in acid medium have been investigated by Ashassi-Sorkhabi et al. Weight loss measurements at temperatures ranging from $25^{\circ} \mathrm{C}$ to $45^{\circ} \mathrm{C}$ were carried out [4]. Tan et al. have studied the synergistic effect of potassium iodide and sodium dodecyl sulfonate on the corrosion inhibition of carbon steel in $\mathrm{HCl}$ medium. Electrochemical test, surface morphology analysis, and molecular simulation approaches were used [5]. El Hamdouni et al. have used Omeprazole as Inhibitor for C38 Steel Corrosion in $1.0 \mathrm{M} \mathrm{H}_{3} \mathrm{PO}_{4}$ Medium. Weight loss tests, potentiodynamic polarization and electrochemical impedance spectroscopy measurements were used. Thermodynamic parameters have also been calculated [6]. Corrosion inhibition effect of expired ampicillin and flucloxacillin drugs for mild steel in aqueous acidic medium has been studied by Alfakeer et al. Weight loss and electrochemical studies were used [7]. Abdulazeez et al. have studied. Inhibition of mild steel corrosion in $\mathrm{CO}_{2}$ and $\mathrm{H}_{2} \mathrm{~S}$-saturated acidic media by a new polyurea-based material. Electrochemical studies and weight loss method were used. The maximum inhibition efficiency achieved was 99.9\% [8]. Figueredo et al. have evaluated Eulychnia acida and Echinopsis chiloensis (Cactaceae) extracts in inhibiting corrosion of carbon steel in $\mathrm{HCl}$ solution. Electrochemical studies were used. A thin protective film was noted [9].

Douche et al. have evaluated anti-corrosion performance of 8-hydroxyquinoline derivatives for mild steel in acidic medium. They have used weight loss method, electrochemical studies and DFT [10].

Nadi et al. [11] have used Sargassum muticum extract to control corrosion of carbon steel in hydrochloric acid pickling environment. They have made use of weight loss method and electrochemical methods. The protective film has been analyzed by surface analysis techniques. 
A powerful nanocomposite polymer prepared from metal oxide nanoparticles synthesized Via brown algae as anti-corrosion and anti-biofilm has been used by Sadek to control corrosion of mild steel in $1 \mathrm{M} \mathrm{HCl}$. AFM, TEM and XRD techniques have been used in this study [12].

In the present study, the inhibitive effect of an alcoholic extract of a seaweed, namely, Sargassum Muticum, in controlling corrosion of mild steel in $0.5 \mathrm{~N} \mathrm{HCl}$ has been evaluated by weight loss method (immersion period 1 day) and electrochemical techniques such as polarization study and AC impedance spectra. The protective film has been investigated by AFM and Vickers Hardness test.

\section{Experimental work}

The inhibitive effect of an alcoholic extract of a seaweed, namely, Sargassum Muticum, in controlling corrosion of mild steel in $0.5 \mathrm{~N} \mathrm{HCl}$ has been evaluated by weight loss and electrochemical techniques such as polarization study and AC impedance spectra. The protective film has been investigated by AFM and Vickers Hardness test.

\section{Mild steel specimens}

The mild steel specimens used for weight loss and surface examination studies were composed of $\mathrm{C} 0.079 \%, \mathrm{P} 0.025 \%, \mathrm{Mn} 0.018 \%, \mathrm{~S} 0.021 \%$ and the remainder $\mathrm{Fe}$ and dimension $5.0 \times 1.0 \times 0.05 \mathrm{~cm}$. For electrochemical techniques, mild steel specimen of above said composition encapsulated in Teflon with an exposed area of $1 \mathrm{~cm}^{2}$ was used. Prior to each experiment, the metal specimens were polished to mirror finish with different grades of emery sheets, washed with double distilled water, degreased using acetone; air dried and preserved. All the corrosive media $(0.5 \mathrm{~N} \mathrm{HCl})$ were prepared by distilled water and standardized.

\section{Seaweed Extract (SWE) preparation}

The seaweed used for this study Sargassum Muticum [13] was collected from Ramanathapuram. The sea weed was air dried completely, powdered and weighed. The extract was prepared by refluxing $5 \mathrm{~g}$ of powdered sea weed in ethanol medium for 8 hours. Then the extract was filtered after one day and placed in an air tight container.

The Sargassum Muticum, was selected for the study due to the presence of the active components. The components of the sea weed extract (Figure 2) of Sargassum Muticum was found to contain the following compounds, namely, geranyl isovalerate, oleic acid, 17-octadecynoic acid, 9,12,15-octadecatrienoic acid, trans-13-octadecenoic acid methyl ester, 6,9,12,15-docosatetraenoic acid methyl ester, gibberellic acid, fenretinide, 9,10-secocholesta, 5,7,10(19)-triene-3,24,25-triol, cholestane-3-o1,2-methylene-2,3dihydroxypropyl ester n-hexadecanoic acid (palmitic acid) [14]. Structures of some important compounds are shown in Figure 2. 


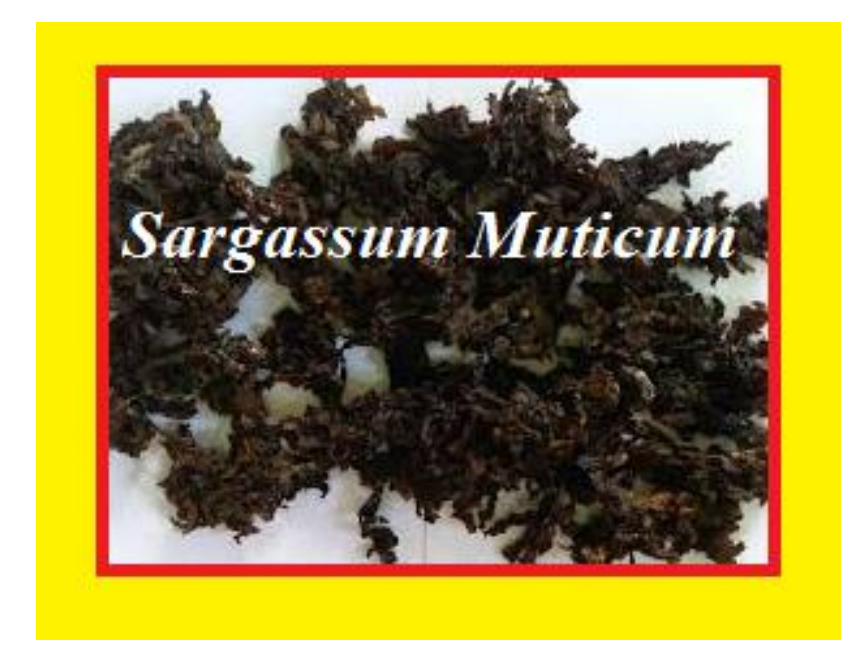

Figure 1. Sargassum Muticum.

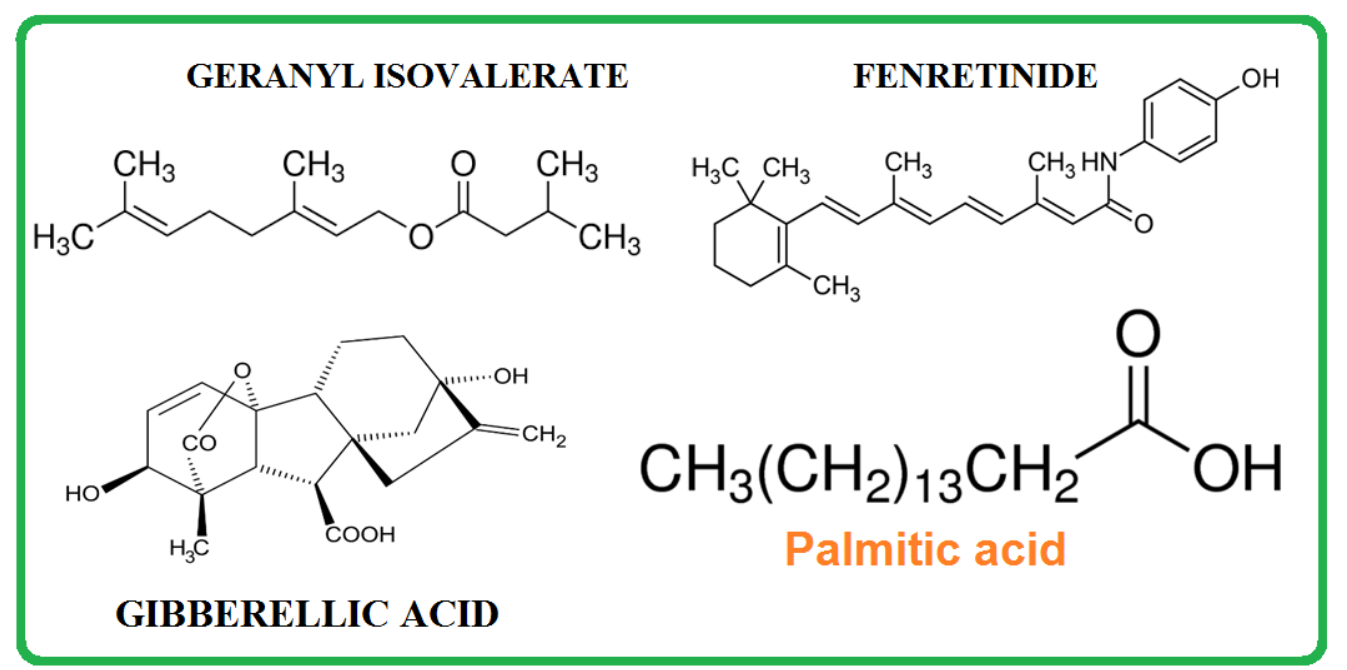

Figure 2. Structures of some important ingredients of the sea weed Sargassum Muticum.

Weight loss method

Weights of the three polished mild steel specimens were measured before and after immersion in various test solutions $(0.5 \mathrm{~N} \mathrm{HCl}$ with different $\mathrm{SWE}$ concentrations) for one day. The inhibition efficiencies were calculated from the relation.

$$
I E=\frac{C R_{1}-C R_{2}}{C R_{1}} \cdot 100 \%
$$

Where $C R_{1}$ is corrosion rate in the absence of inhibitor and $C R_{2}$ is the corrosion rate in the presence of inhibitor.

Langmuir adsorption isotherm

In this study importance is given to blocking (blanket) effect. The inhibitor molecules are adsorbed on the metal surface as monolayers. The blanket effect is responsible for the 
corrosion inhibition efficiency of the inhibitors, namely, the active principles present in the alcoholic extract of the sea weed Sargassum Muticum.

There are various types of adsorption isotherms such as Langmuir, Freundlich and Temkin. In the case of Langmuir adsorption isotherm, a plot of $C v s$. $C / \theta$ gives a straight line. Where $C$ is concentration of the inhibitor in ppm and $\theta$ is surface coverage.

$$
\theta=\frac{\% I E}{100}
$$

\section{Electrochemical study}

In the present work corrosion resistance of mild steel immersed in various test solutions were measured by polarization study and AC impedance spectra. Electrochemical measurements were performed in an Ivium CompactStat electrochemical measurement unit.

\section{Polarization study}

Polarization studies were carried out in a three-electrode cell assembly (Figure 3). A SCE was the reference electrode. Platinum was the counter electrode. Mild steel was the working electrode. From polarization study, corrosion parameters such as corrosion potential $\left(E_{\text {corr }}\right)$, corrosion current $\left(I_{\text {corr }}\right)$, Tafel slopes anodic $=b_{\mathrm{a}}$ and cathodic $=b_{\mathrm{c}}$, and $L P R$ (linear polarisation resistance) values were measured.

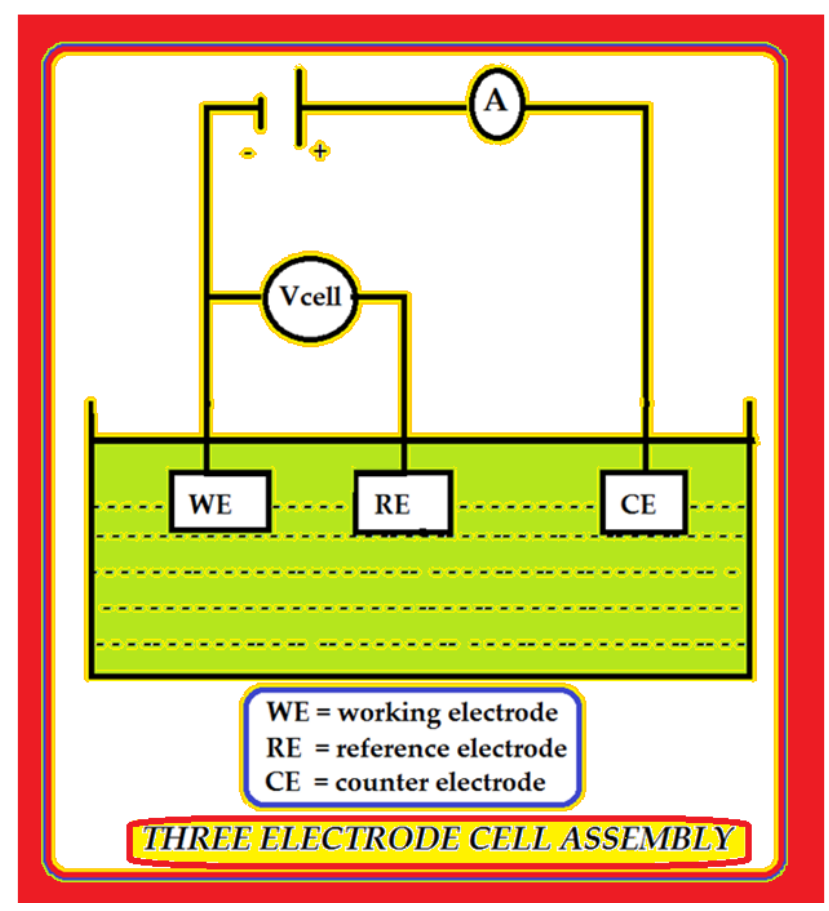

Figure 3. Three-electrode cell assembly. 


\section{AC impedance spectra}

The same instrument and set-up used for polarization study were used to record AC impedance spectra also. The real part $\left(Z^{\prime}\right)$ and imaginary part $\left(-Z^{\prime \prime}\right)$ of the cell impedance were measured in Ohms at various frequencies. From Nyquist plot the values of charge transfer resistance $\left(R_{\mathrm{t}}\right)$ and the double layer capacitance $\left(C_{\mathrm{dl}}\right)$ were calculated. From Bode plots impedance values, and phase angle values were derived.

\section{Vickers hardness}

The carbon steel specimens immersed in various test solutions for one day were taken out, rinsed with double distilled water, dried and subjected to Vickers hardness measurement, by Shimadzu make model HMV-27.

\section{Atomic force microscopy (AFM)}

The carbon steel specimens immersed in various test solutions for one day were taken out, rinsed with double distilled water, dried and subjected to the surface examination. The surface morphology measurements of the carbon steel surface were carried out by atomic force microscopy (AFM) using SPM Veeco diInnova connected with the software version V7.00 and a scan rate of $0.7 \mathrm{~Hz}$.

\section{Results and discussion}

\section{Weight loss method}

Corrosion resistance of mild steel (MS) in $0.5 \mathrm{~N} \mathrm{HCl}$, in presence of an inhibitor namely an alcoholic extract of a seaweed Sargassum Muticum has been evaluated by weight loss method. The results are given in Table 1. It is observed from the Table 1 that sea weed (Sargassum Muticum) extract has some inhibition efficiency (IE). As the concentration of seaweed extract increases, surface coverage $(\theta)$ increases, corrosion rate $(C R)$ decreases and inhibition efficiency $(I E, \%)$ increases (Figure 4) because of blocking effect.

Table 1. Corrosion rate and inhibition efficiency of seaweed extract in controlling corrosion of mild steel in $0.5 \mathrm{~N} \mathrm{HCl}$ obtained from weight loss method.

\begin{tabular}{cccc}
\hline Inhibitor $(\mathbf{p p m})$ & Corrosion rate $(\mathbf{m m p g})$ & IE\% & Surface Coverage $(\boldsymbol{\theta})$ \\
\hline 0 & 5.38 & - & - \\
100 & 0.5918 & 89 & 0.89 \\
200 & 0.5380 & 90 & 0.90 \\
300 & 0.3766 & 93 & 0.93 \\
400 & 0.1076 & 98 & 0.98 \\
500 & 0.0538 & 99 & 0.99 \\
\hline
\end{tabular}




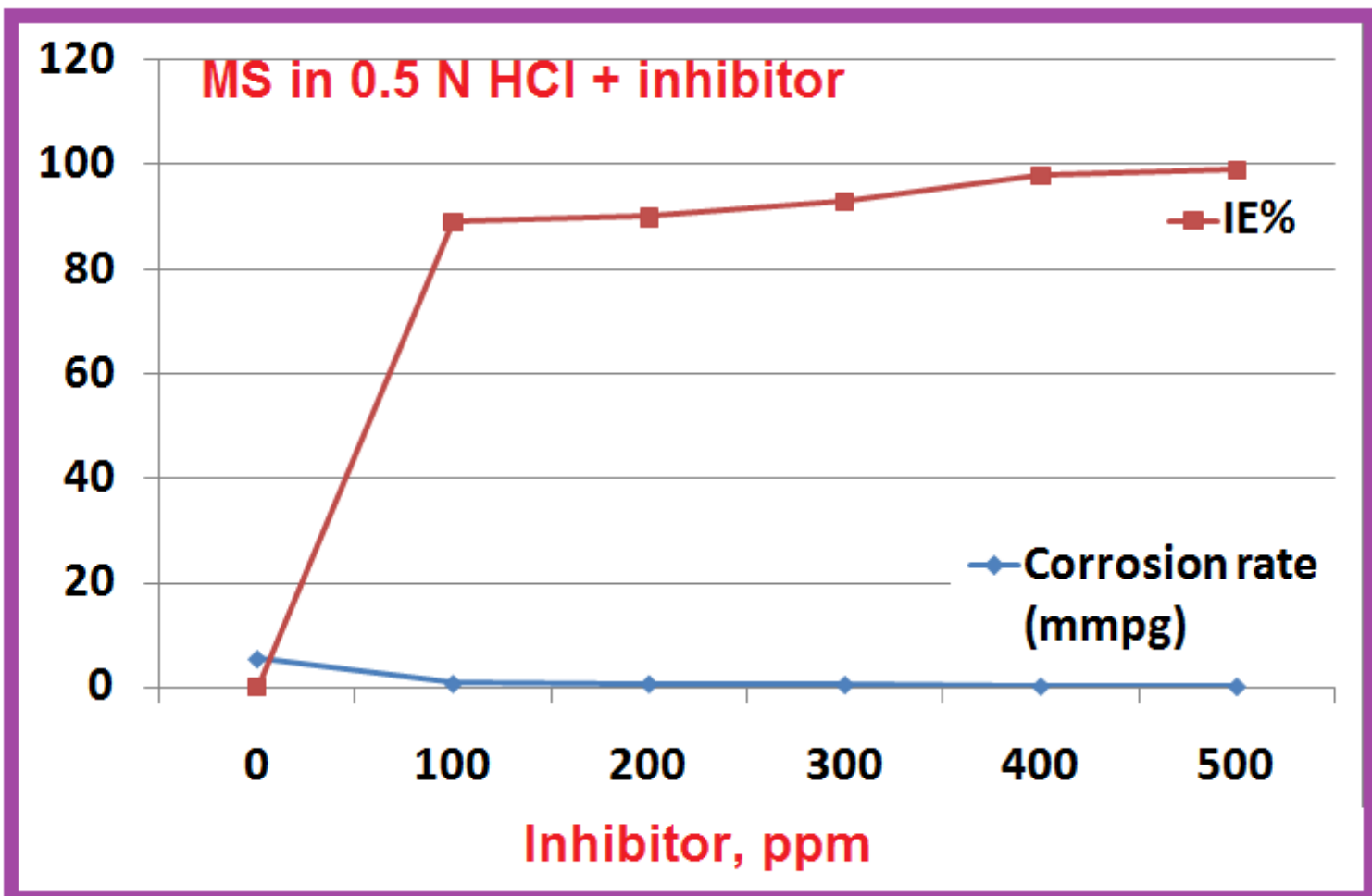

Figure 4. In the presence of the inhibitor, corrosion rate decreases and inhibition efficiency increases.

This is mainly due to the Blocking (Blanket) effect of the adsorbed inhibitor molecules (Figure 5) on the metal surface [15-18].

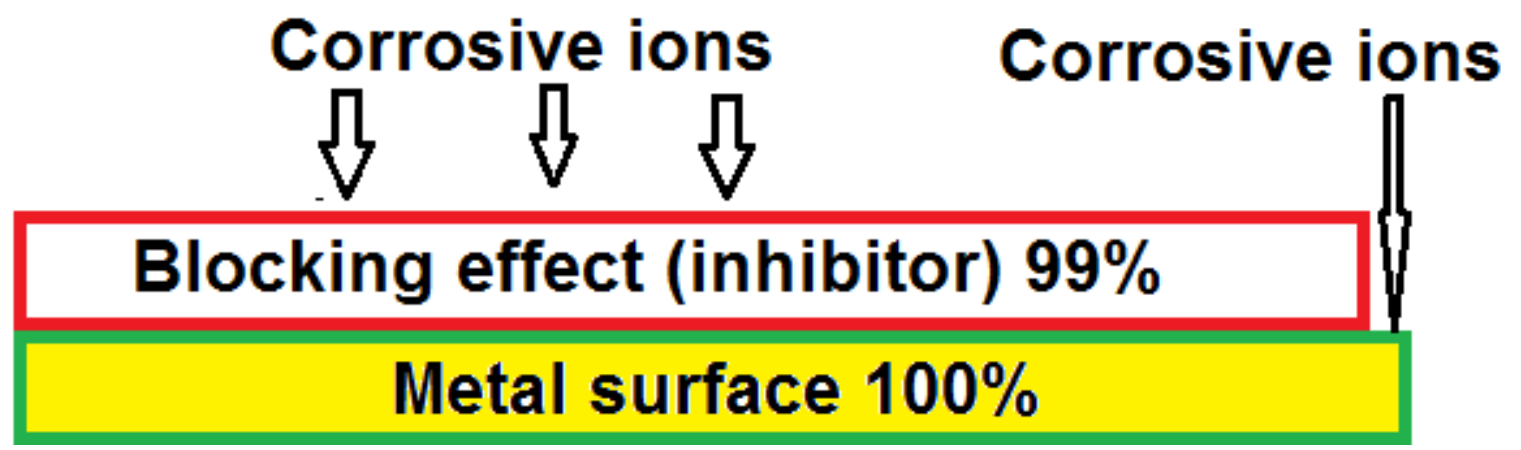

Figure 5. Blocking (blanket) effect.

\section{Langmuir adsorption isotherm}

The Langmuir adsorption isotherm is used to describe the equilibrium between adsorbate and adsorbent system, where the adsorbate adsorption is limited to one molecular layer. In this study blocking effect of the adsorbed molecules of the inhibitor is taken into account. Based on this concept the surface coverage was calculated by the relation, surface coverage $\theta=I E \% / 100$. Corrosion takes place at uncovered area (Figure 5). The parameters needed for the plot of Langmuir adsorption isotherm are given in Table 2. The plot of concentration of 
inhibitor ( $C, \mathrm{ppm})$ vs $C / \theta$ gives a straight line with $R^{2}$ value of 0.998 (Figure 6). The surface coverage is of one molecular layer of inhibitors. Multilayer is not possible.

Table 2. Parameters needed for the plot of Langmuir adsorption isotherm.

\begin{tabular}{ccc}
\hline $\boldsymbol{C}, \mathbf{p p m}$ (inhibitor) & Surface Coverage $(\boldsymbol{\theta})$ & $\boldsymbol{C} / \boldsymbol{\theta}$ \\
\hline 100 & 0.89 & 112.35 \\
200 & 0.90 & 222.22 \\
300 & 0.93 & 322.58 \\
400 & 0.98 & 408.16 \\
500 & 0.99 & 505.05 \\
\hline
\end{tabular}

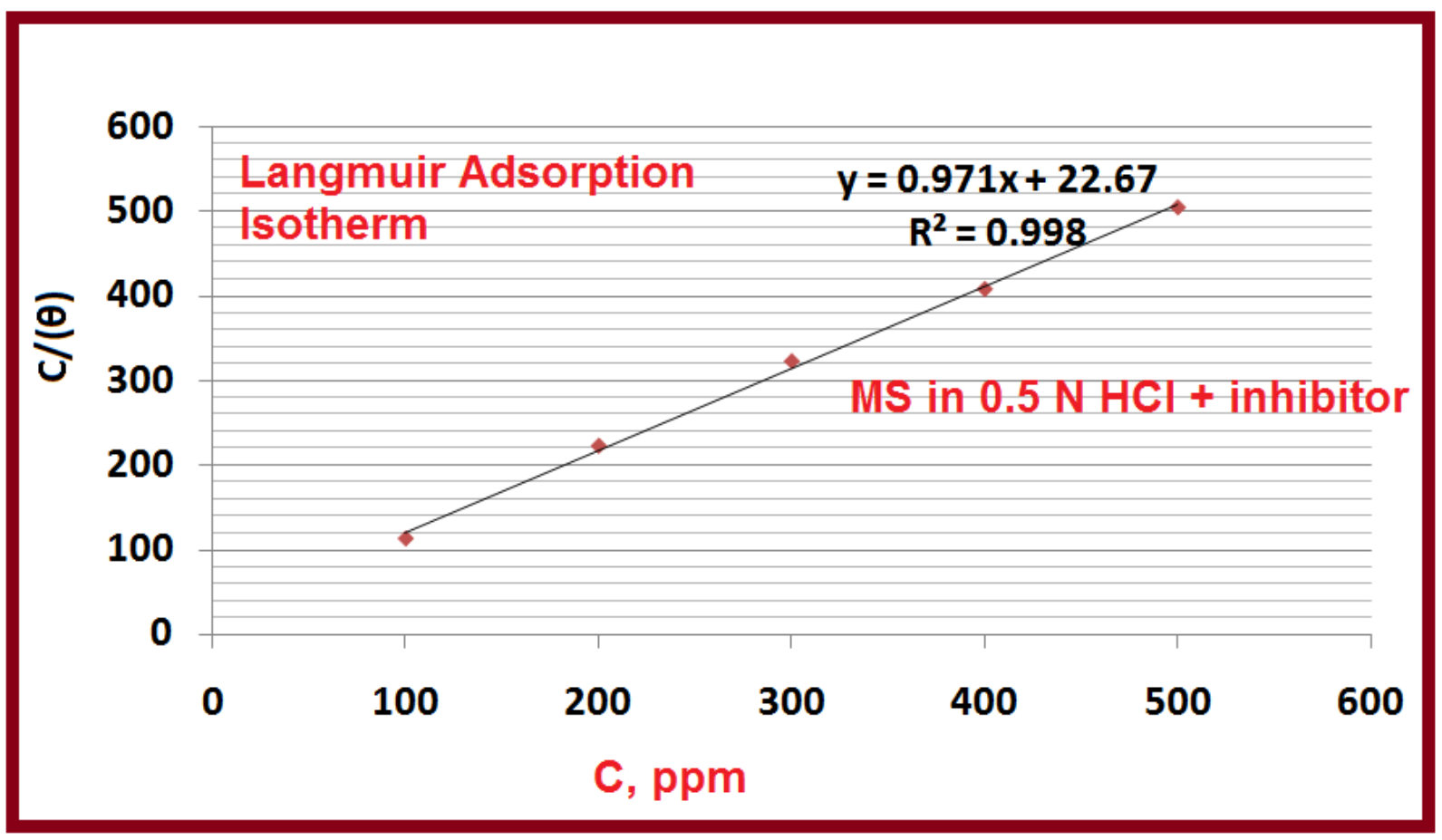

Figure 6. Langmuir adsorption isotherm.

\section{Electrochemical studies}

Electrochemical studies such as AC impedance spectra and polarisation study have been employed in corrosion inhibition study [19-33]. When corrosion resistance increases because of blocking effect (Blanket effect) of adsorbed inhibitor molecules on the metal surfaces, the following observations are noted: linear polarisation resistance $(L P R)$ value increases, corrosion current $\left(I_{\text {corr }}\right)$ decreases, charge transfer $\left(R_{\mathrm{ct}}\right)$ value increases, double layer capacitance $\left(C_{\mathrm{dl}}\right)$ decreases, impedance increases and phase angle increases (Figure 7$)$. 


\section{Blocking effect (Blanket effect)}

\section{Corrosion resistance increases}

LPR value increases

$\mathrm{I}_{\text {corr }}$ decreases

$R_{t}$ value increases

$C_{d l}$ value decreases

Impedance increases

Phase angle increases

Figure 7. Correlation among corrosion parameters and blocking effect.

\section{Analysis of AC impedance spectra}

Electrochemical impedance spectroscopy (EIS) is a powerful technique that utilizes a small amplitude, alternating current (AC) signal to probe the impedance characteristics of a cell. The AC signal is scanned over a wide range of frequencies to generate an impedance spectrum for the electrochemical cell under test. A three electrode cell assembly is used for this purpose (Figure 3). In AC Impedance spectra, when corrosion resistance increases because of blocking effect (blanket effect) of adsorbed inhibitor molecules on the metal surfaces, charge transfer $\left(R_{\mathrm{ct}}\right)$ value increases, double layer capacitance $\left(C_{\mathrm{dl}}\right)$ decreases, impedance increases and phase angle increases (Figure 7). Corrosion parameters of seaweed extract in controlling corrosion of mild steel in $0.5 \mathrm{~N} \mathrm{HCl}$ obtained from $\mathrm{AC}$ impedance spectra (immersion period one day) are given in Table 3. It is observed that as the concentration of inhibitor increase, $R_{\mathrm{ct}}$ value increase and $C_{\mathrm{dl}}$ value increases double layer capacitance $\left(C_{\mathrm{dl}}\right)$ decreases, impedance increases and phase angle increases (Figure 7$)$ due to the formation of blocking effect on the metal surface. It is found to be a monolayer of protective film. The AC impedance spectra are shown in Figures 8-10.

Table 3. Corrosion parameters of seaweed extract (Sargassum Muticum) in controlling corrosion of mild steel in $0.5 \mathrm{~N} \mathrm{HCl}$ obtained from $\mathrm{AC}$ impedance spectra (immersion period one day).

\begin{tabular}{|c|c|c|c|c|}
\hline $\begin{array}{c}\text { Inhibitor } \\
\text { ppm }\end{array}$ & $\begin{array}{c}O C P \\
\mathrm{~V}\end{array}$ & $\begin{array}{c}R_{\mathrm{ct}} \\
\mathrm{Ohm} \cdot \mathrm{cm}^{2}\end{array}$ & $\begin{array}{c}C_{\mathrm{dl}} \\
\left(\mu \mathrm{F} / \mathrm{cm}^{2}\right)\end{array}$ & Inhibition efficiency, \% \\
\hline 0 & -0.345 & 12.184 & 19.1 & - \\
\hline 100 & -0.342 & 18.769 & 18.9 & 87.69 \\
\hline 200 & -0.341 & 35.953 & 18.5 & 89.12 \\
\hline
\end{tabular}




\begin{tabular}{ccccc}
\hline $\begin{array}{c}\text { Inhibitor } \\
\mathbf{p p m}\end{array}$ & $\begin{array}{c}\boldsymbol{O C P} \\
\mathbf{V}\end{array}$ & $\begin{array}{c}\boldsymbol{R}_{\mathbf{c t}} \\
\mathbf{O h m} \cdot \mathbf{c m}^{\mathbf{2}}\end{array}$ & $\begin{array}{c}\boldsymbol{C}_{\mathbf{d l}} \\
\left(\boldsymbol{\mu} \mathbf{F} / \mathbf{c m}^{2}\right)\end{array}$ & Inhibition efficiency, \% \\
\hline 300 & -0.332 & 28.479 & 18.1 & 93.10 \\
400 & -0.329 & 93.47 & 16.9 & 99.17 \\
500 & -0.321 & 71.9 & 17.3 & 98.91 \\
\hline
\end{tabular}

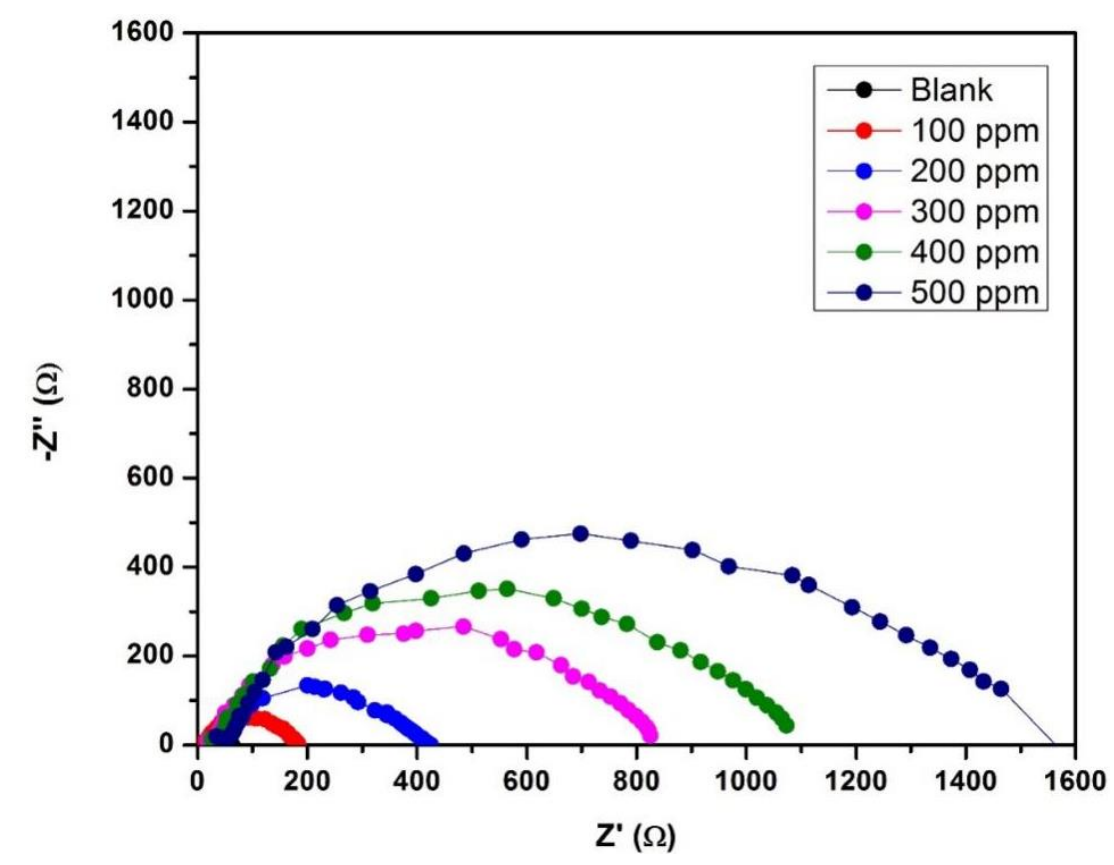

Figure 8. Nyquist plots of various test solutions.

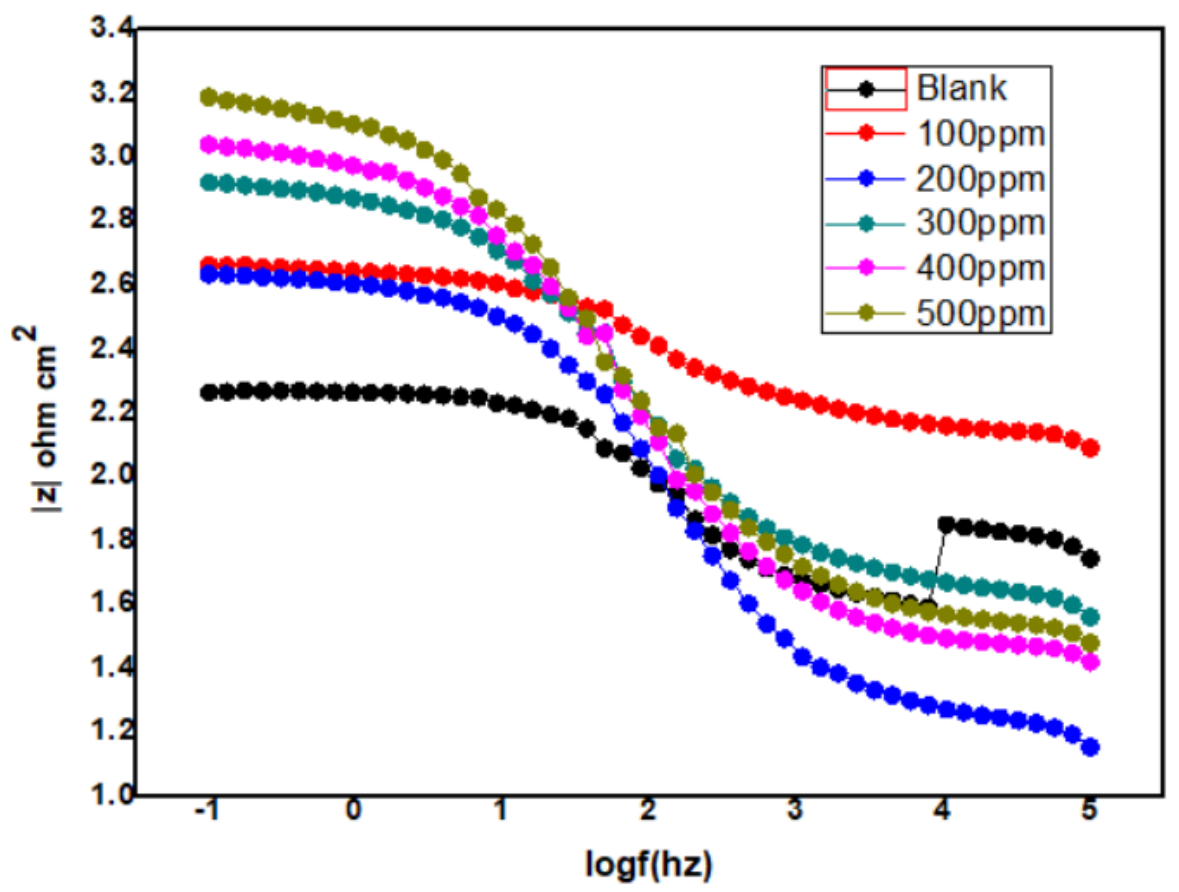

Figure 9. Bode plots (impedance) of various test solutions. 


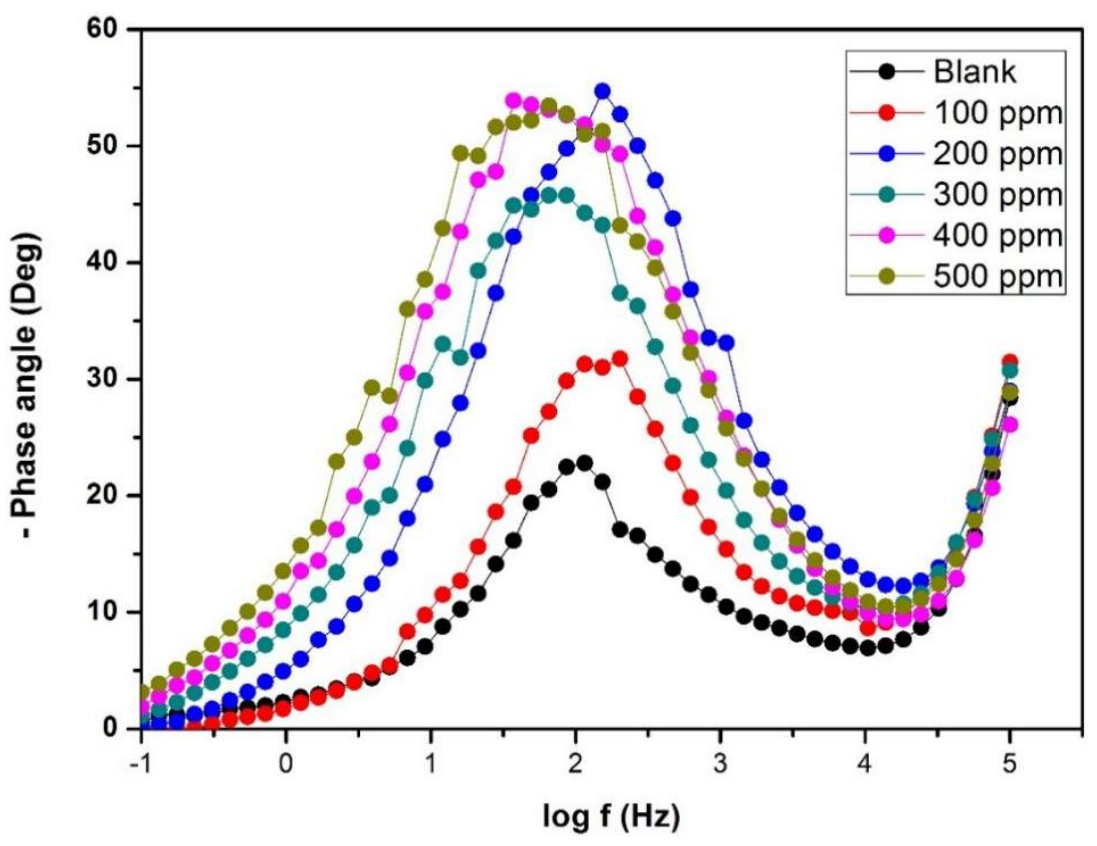

Figure 10. Bode plots (phase angle) of various test solutions.

The Nyquist plot in Figure 8 results from the electrical circuit of Figure 4. The semicircle is characteristic of a single "time constant". Often only a portion of a semicircle is seen. The equivalent circuit diagram is shown in Figure 11.

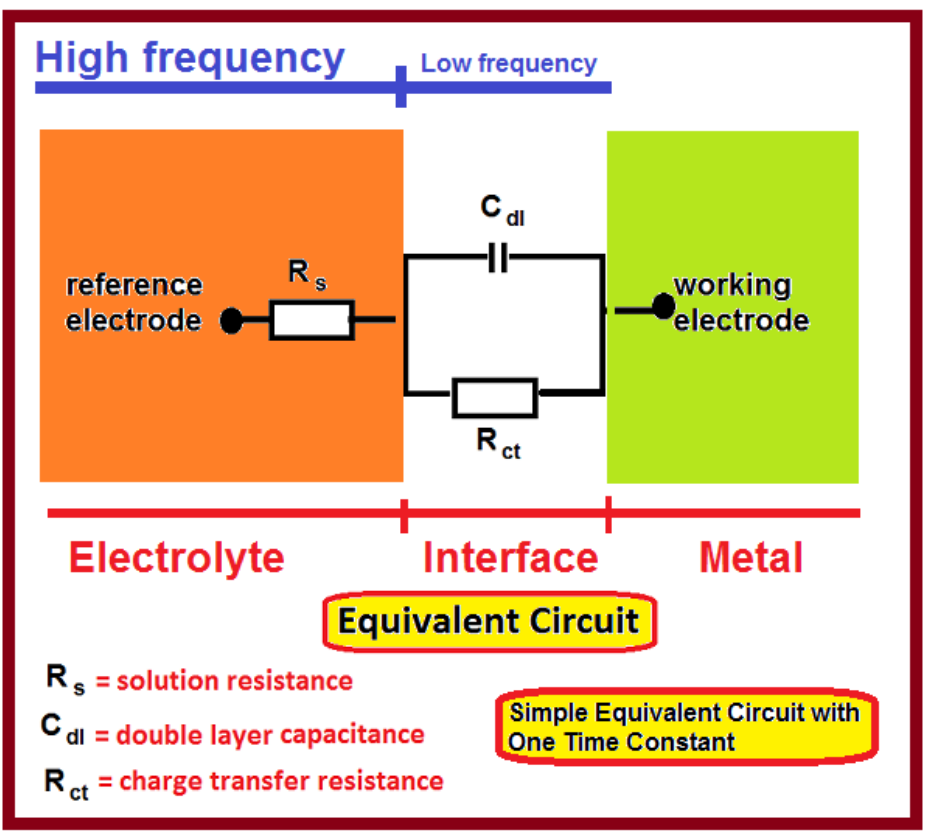

Figure 11. Equivalent circuit with one time constant.

\section{Polarization Study}

The polarization curves of mild immersed in $0.5 \mathrm{~N} \mathrm{HCl}$ in the absence and presence of inhibitor are shown in Figure 12 and the corrosion parameters are given in Tables 4 and 5. 


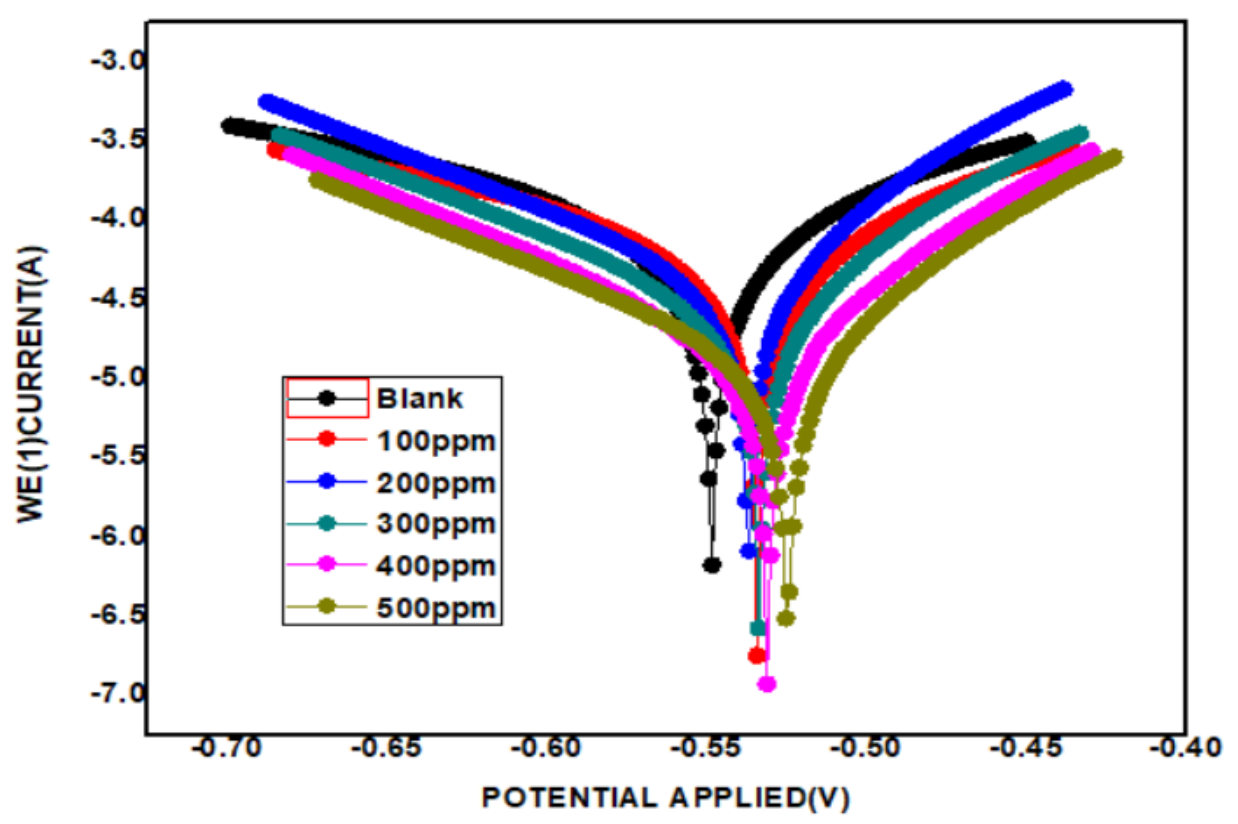

Figure 12. Tafel plots of mild steel immersed in $0.5 \mathrm{~N} \mathrm{HCl}$ and inhibitor solutions (1 Day).

Table 4. Corrosion parameters of mild steel immersed in $0.5 \mathrm{~N} \mathrm{HCl}$ in presence of an alcoholic extract of sea weed extract obtained from polarisation study (immersion period one day).

\begin{tabular}{cccccc}
\hline \multirow{2}{*}{$\begin{array}{c}\text { Inhibitor } \\
(\mathbf{p p m})\end{array}$} & $\begin{array}{c}\boldsymbol{E}_{\mathbf{c o r r}} \\
(\mathbf{V} / \mathbf{S C E})\end{array}$ & $\begin{array}{c}\boldsymbol{b}_{\mathbf{c}} \\
(\mathbf{m V} / \mathbf{d e c a d e})\end{array}$ & $\begin{array}{c}\text { Tafel Plot } \\
(\mathbf{m V} / \mathbf{d e c a d e})\end{array}$ & $\begin{array}{c}\boldsymbol{L P R} \\
\mathbf{O h m} \cdot \mathbf{c m}^{\mathbf{2}}\end{array}$ & $\begin{array}{c}\boldsymbol{I}_{\mathbf{c o r r}} \\
\mathbf{A} / \mathbf{c m}^{2}\end{array}$ \\
\cline { 3 - 5 } & -0.5407 & 315 & 477 & 368.42 & $2.24 \cdot 10^{-5}$ \\
100 & -0.5291 & 245 & 521 & 470.08 & $2.75 \cdot 10^{-5}$ \\
200 & -0.5467 & 083 & 147 & 465.23 & $2.21 \cdot 10^{-5}$ \\
300 & -0.5337 & 089 & 144 & 773.14 & $1.54 \cdot 10^{-5}$ \\
400 & -0.5160 & 085 & 134 & 1887.1 & $8.57 \cdot 10^{-6}$ \\
500 & -0.5122 & 885 & 122 & 1729.2 & $1.82 \cdot 10^{-6}$ \\
\hline
\end{tabular}

Table 5. Corrosion parameters of MS Alloy in SW extract solution for one day polarization study.

\begin{tabular}{cc}
\hline Inhibitor $(\mathbf{p p m})$ & Corrosion rate $(\mathbf{m m} / \mathbf{y})$ \\
\hline 0 & 2.5989 \\
100 & 1.7905 \\
200 & 0.57342 \\
300 & 0.35863 \\
400 & 0.22112 \\
500 & 0.18405 \\
\hline
\end{tabular}


It is observed from Table 5 that when concentration of inhibitor increases the corrosion rate decreases (Figure 13).

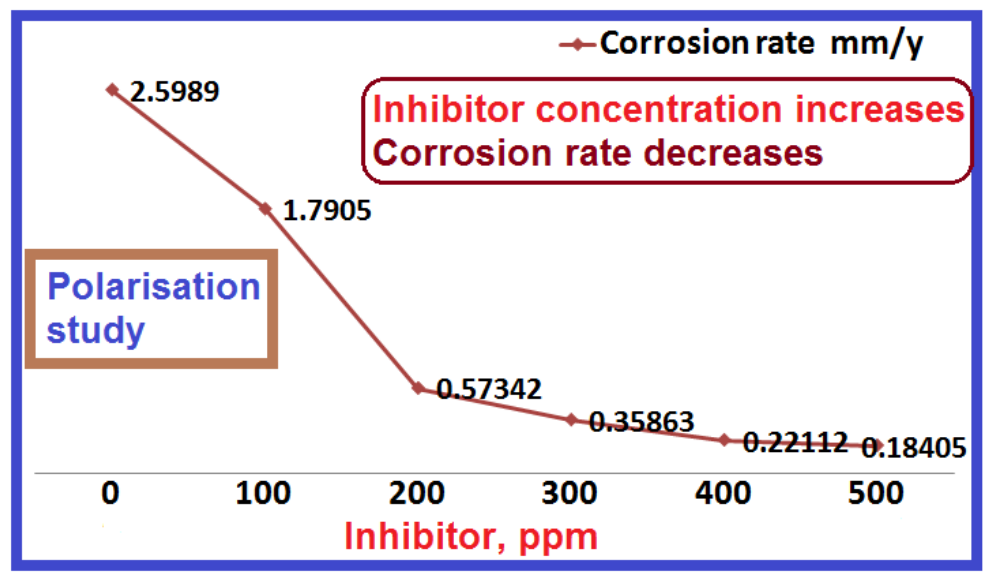

Figure 13. Corrosion rate and inhibitor concentration.

Corrosion parameters of mild steel immersed in $0.5 \mathrm{~N} \mathrm{HCl}$ in presence of an alcoholic extract of sea weed extract obtained from polarisation study (immersion period one day) are given in Tables 4 and 5. The Tafel plots are shown in Figure 12. Various concentrations of the inhibitor are used. It is observed that in presence of inhibitor the corrosion potential shifts to the anodic side. This suggests that the anodic reaction is controlled predominantly. Nevertheless, the shift is within $50 \mathrm{mV}$. Hence it is inferred that the inhibitor functions as mixed type of inhibitor controlling both anodic reaction and cathodic reaction (Figure 14). This can be explained by the blocking (blanket) effect of inhibitor. It is also observed that in presence of inhibitor, the $L P R$ value increases and corrosion current value decreases. Because of the Blanket effect (formation of protective film on the metallic surface blocking anodic sites and cathodic sites), electron transfer from the metal to the bulk of the solution is blocked. Further the anodic sites and cathodic sites are blocked by the inhibitor molecules. Hence electrons cannot be transferred from anodic sites to cathodic sites. So, decrease in corrosion current is also noticed from the Table 4. As the concentration of inhibitor increases, the blanket effect also increases.

$$
\begin{array}{ll}
\text { Reactions in acid medium } \\
\text { At anode : } & \mathrm{Fe} \longrightarrow \mathrm{Fe}^{2+}+2 \mathrm{e}- \\
\text { At cathode : } & 2 \mathrm{H}^{+}+2 \mathrm{e}-\Rightarrow \mathrm{H}_{2(\mathrm{~g})} \\
\text { Overall reaction: } & \mathrm{Fe}+2 \mathrm{H}^{+} \Rightarrow \mathrm{Fe}^{2+}+\mathrm{H}_{2(\mathrm{~g})}
\end{array}
$$

At anode : Generation of electron and formation of metal ion

At cathode : Neutralisation of protons by electrons with evolution of hydrogen gas

Overall reaction: Formation of metal ion and evolution of Hydrogen gas

Figure 14. Anodic reaction and cathodic reaction in acid medium corrosion of metal. 


\section{Analysis of Vickers hardness}

The Vickers hardness was measured for polished mild steel surface (system A), polished mild steel immersed in corrosive medium $(0.5 \mathrm{~N} \mathrm{HCl})$ (system $\mathrm{B}$ ) and polished mild steel surface immersed in corrosive medium $(0.5 \mathrm{~N} \mathrm{HCl})$ containing the inhibitor (alcoholic extract of sea weed) (system C). The values are given in Table 6.

Table 6. Vickers hardness of various metal surfaces.

\begin{tabular}{ccccc}
\hline System & Load & $\boldsymbol{L}_{\mathbf{1}}$ & $\boldsymbol{L}_{\mathbf{2}}$ & $\boldsymbol{H V}$ \\
\hline Polished metal & $300 \mathrm{~g}$ & 54.45 & 55.26 & 185 \\
Corroded metal & $300 \mathrm{~g}$ & 70.27 & 72.59 & 109 \\
Inhibited metal & $300 \mathrm{~g}$ & 70.79 & 70.27 & 112 \\
\hline
\end{tabular}

The Vickers hardness was measured for $300 \mathrm{~g}$ load. It is observed that for system A the hardness is high. For system B the hardness is low because the corroded surface contains iron oxide film which is porous and amorphous and so the surface is very rough. Pits are noticed due to corrosion. For system $C$ the surface is smooth, due to the formation of protective film. The hardness is in between that of system A and B (Figure 15). That is lower than that of polished metal but higher than that of corroded surface. The hardness values are given in Table 6. Thus the Vickers hardness is used in corrosion inhibition study.

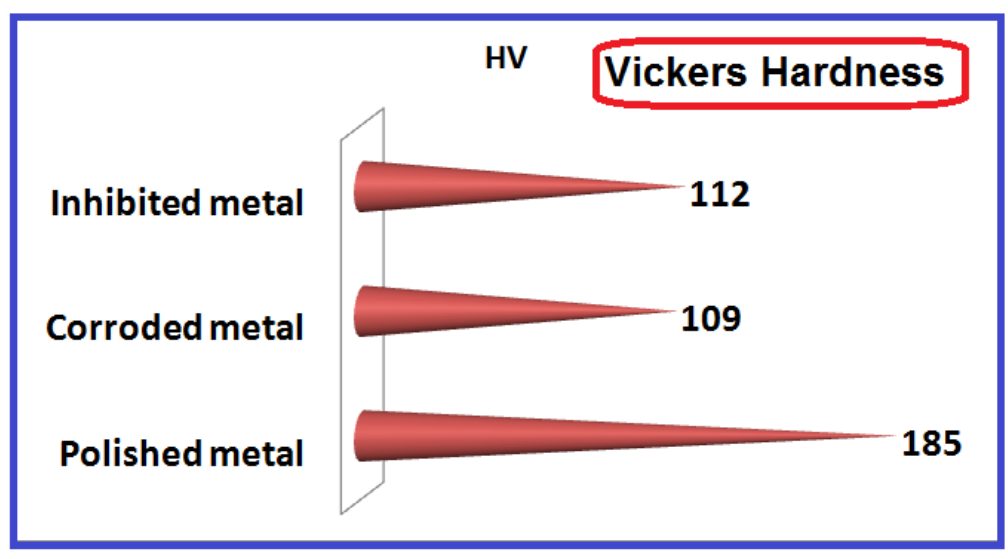

Figure 15. Comparison of Vickers hardness of various metal surfaces.

\section{Application of Atomic force microscopy (AFM)}

Atomic force microscopy is used widely in corrosion inhibition study. The roughness of the metal surface can be investigated and measured for three systems, namely polished metal (system A), polished metal immersed in the blank solution (system B) and polished metal immersed in the inhibitor system (system $\mathrm{C}$ ). The average roughness $(R a)$, the root mean square (RMS) roughness $(R q)$ and maximum peak-to-valley height can be derived from AFM images. In general, among the three systems, A, B and C the average roughness 
is in following order $\mathrm{B}>\mathrm{C}>\mathrm{A}$. This indicates that a protective film is formed on the metal surface in presence of inhibitor and hence corrosion inhibition efficiency increases. The average roughness, RMS roughness and maximum peak-to-valley height are in the order $\mathrm{B}>\mathrm{C}>\mathrm{A} .2 \mathrm{D}$ images and 3D images are produced in AFM study. Section analysis is also given (Figures 16-18). AFM data for mild steel immersed in various test solutions in the absence and presence of inhibitor system are given in Table 7.

Table 7. AFM data for mild steel immersed in various test solutions in the absence and presence of inhibitor system.

\begin{tabular}{cccc}
\hline Samples & $\begin{array}{c}\text { Average }(\boldsymbol{R a}) \\
\text { roughness }(\mathbf{n m})\end{array}$ & $\begin{array}{c}\text { RMS }(\boldsymbol{R q}) \text { roughness } \\
(\mathbf{n m})\end{array}$ & $\begin{array}{c}\text { Maximum peak-to- } \\
\text { valley height }(\mathbf{n m})(\boldsymbol{R y})\end{array}$ \\
\hline Polished metal (A) & 98.65 & 116.89 & 477.84 \\
$\begin{array}{c}\text { Polished metal in } \\
\text { corrosive medium: } \\
0.5 \mathrm{~N} \mathrm{HCl} \mathrm{(B)}\end{array}$ & 410.15 & 515.64 & 2275.1 \\
$\begin{array}{c}\text { Polished metal in } \\
\text { corrosive medium: }\end{array}$ & 389.1 & & \\
$0.5 \mathrm{~N} \mathrm{HCl+inhibitor} \mathrm{(C)}$ & & 468.22 & 2352.6 \\
\hline
\end{tabular}

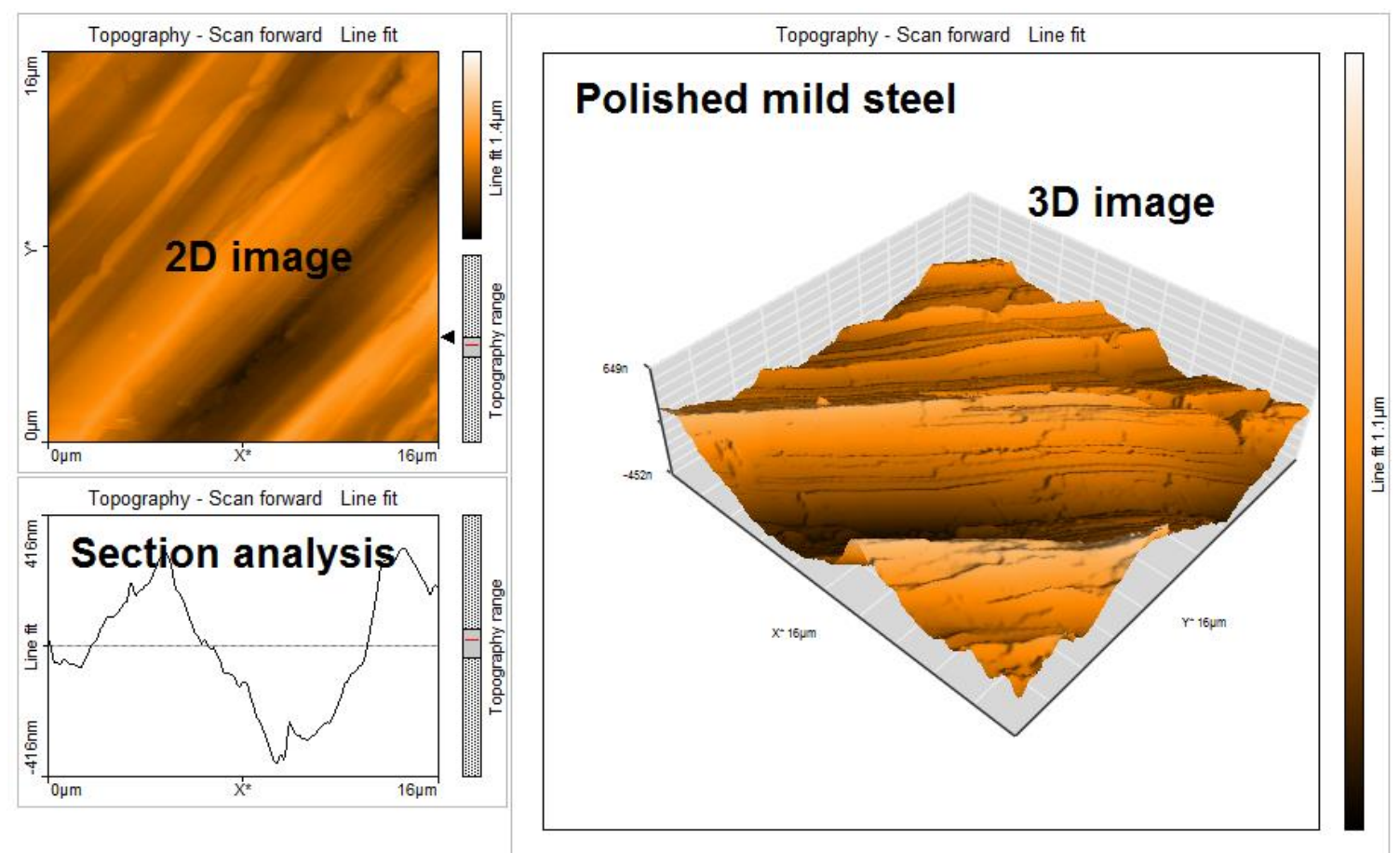

Figure 16. 2D, 3D images and section analysis for polished metal. 


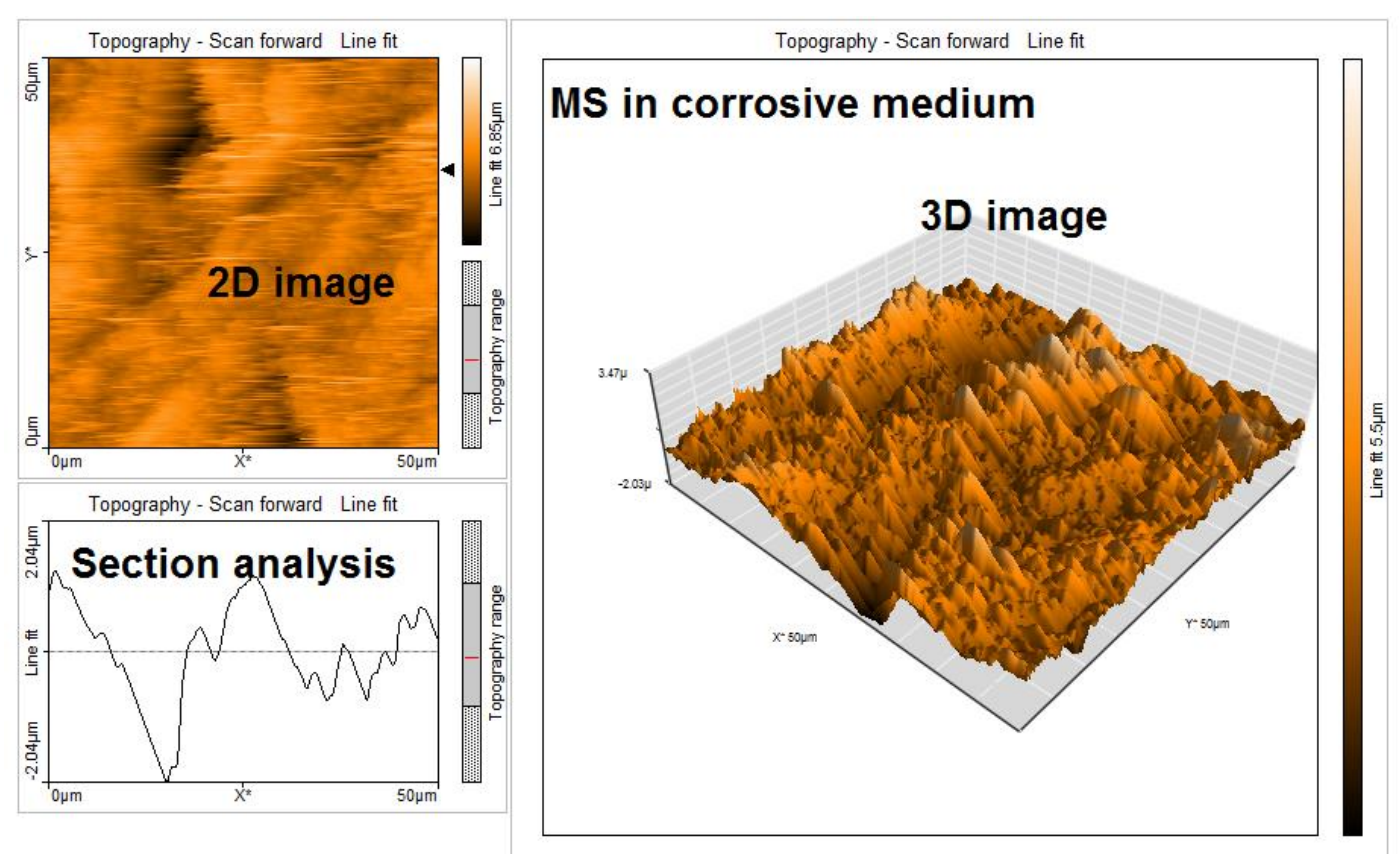

Figure 17. 2D, 3D images and section analysis for corroded metal.

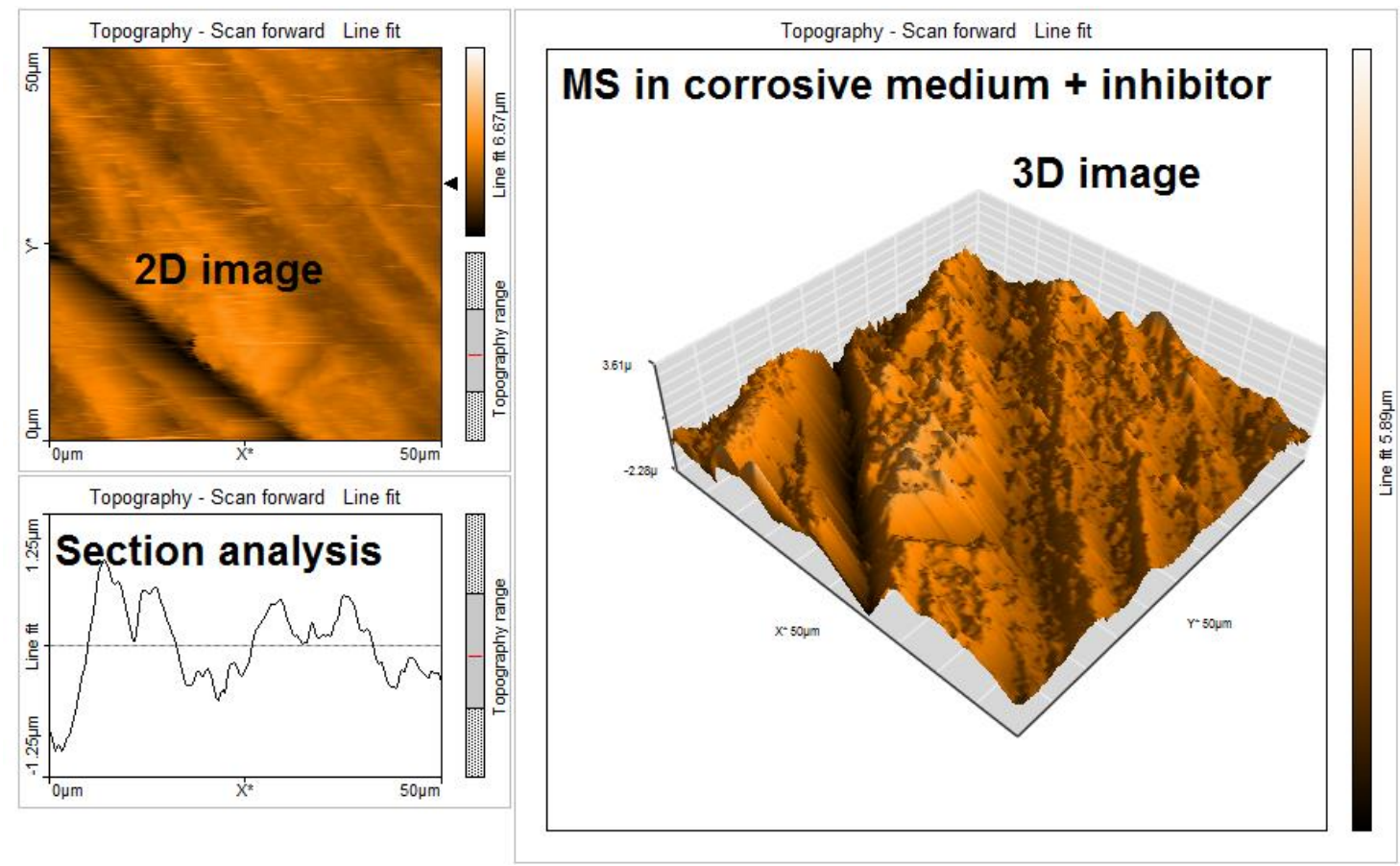

Figure 18. 2D, 3D images and section analysis for inhibited metal.

On the basis of these findings, we can introduce that the excellent inhibitory effect of Sargassum Muticum is due essentially to the synergistic intermolecular effect of various components of the natural extract existing at various concentrations [34-36]. 


\section{Summary and conclusions}

The inhibitive effect of an alcoholic extract of a seaweed, namely, Sargassum Muticum, in controlling corrosion of mild steel in $0.5 \mathrm{~N} \mathrm{HCl}$ has been evaluated by weight loss method (immersion period one day) and electrochemical techniques such as polarization study and AC impedance spectra. The protective film has been investigated by AFM and Vickers Hardness test.

- Weight loss method reveals that 500 ppm of inhibitor offers $99 \%$ inhibition efficiency to mild steel immersed in $0.5 \mathrm{~N} \mathrm{HCl}$.

- The adsorption of inhibitor molecules on the metal surface obeys Langmuir adsorption isotherm. The $R^{2}$ value is very high 0.998 .

- Polarization study reveals that the corrosion potential is slightly shifted to anodic side. It is inferred that the inhibitor solution functions as mixed type of corrosion inhibitor.

- In presence of inhibitor, linear polarization resistance $(L P R)$ value increases and corrosion current value decreases.

- Because of the blanket effect (formation of protective film on the metallic surface blocking anodic sites and cathodic sites), electron transfer from the metal to the bulk of the solution is blocked.

- AC impedance spectra confirm the formation of protective film on the metal surface.

- As the concentration of inhibitor increases, $R_{\mathrm{ct}}$ value increases and double layer capacitance $\left(C_{\mathrm{dl}}\right)$ decreases, impedance increases and phase angle increases due to the formation of blocking effect on the metal surface.

- It is found to be a monolayer of protective film.

- Vickers hardness of the inhibited metal surface is lower than that of polished metal but higher than that of corroded surface.

- The average roughness, RMS roughness and maximum peak -to -valley height of inhibited metal surface are lower than those of corroded metal surface but higher than those of polished metal surface.

- The outcome of the study may be used in pickling industry where $\mathrm{HCl}$ is used to remove the rust and at the same time metal surface is protected.

\section{References}

1. M. Rbaa, M. Fardioui, C. Verma, A.S. Abousalem, M. Galai, E.E. Ebenso, T. Guedira, B. Lakhrissi, I. Warad and A. Zarrouk, 8-Hydroxyquinoline based chitosan derived carbohydrate polymer as biodegradable and sustainable acid corrosion inhibitor for mild steel: Experimental and computational analyses, Int. J. Biol. Macromol., 2020, 155, 645-655. doi: 10.1016/j.ijbiomac.2020.03.200 
2. L. Guo, J. Tan, S. Kaya, S. Leng, Q. Li and F. Zhang, Multidimensional insights into the corrosion inhibition of 3,3-dithiodipropionic acid on Q235 steel in sulphuric acid medium: A combined experimental and in silico investigation, J. Colloid Interface Sci., 2020, 570, 116-124. doi: 10.1016/i.jcis.2020.03.001

3. N. Soltani, N. Tavakkoli, A. Attaran, B. Karimi and M. Khayatkashani, Inhibitory effect of Pistacia khinjuk aerial part extract for carbon steel corrosion in sulfuric acid and hydrochloric acid solutions Soltani, Chem. Pap., 2020, 74, 1799-1815. doi: 10.1007/s11696-019-01026-y

4. H. Ashassi-Sorkhabi and A. Kazempour, Thermodynamic and kinetic insights into the role of amino acids in improving the adhesion of iota-carrageenan as a natural corrosion inhibitor to the aluminum surface, J. Adhes. Sci. Technol., 2020,34, no. 9, 961-975. doi: $\underline{10.1080 / 01694243.2019 .1690776}$

5. J. Tan, L. Guo, H. Yang and F. Zhang, Synergistic effect of potassium iodide and sodium dodecyl sulfonate on the corrosion inhibition of carbon steel in $\mathrm{HCl}$ medium: A combined experimental and theoretical investigation, $R S C A d v$., 2020, 10, no. 26, 15163-15170. doi: 10.1039/D0RA02011G

6. Y.El Hamdouni, F. Bouhlal, H. Kouri, M. Chellouli, M. Benmessaoud, A. Dahrouch, N. Labjar and S.El Hajjaji, Use of omeprazole as inhibitor for C38 steel corrosion in 1.0 $\mathrm{M} \mathrm{H}_{3} \mathrm{PO}_{4}$ medium, J. Fail. Anal. Prev., 2020, 20, 563-571. doi: 10.1007/s11668$\underline{020-00862-5}$

7. M. Alfakeer, M. Abdallah and A. Fawzy, Corrosion inhibition effect of expired ampicillin and flucloxacillin drugs for mild steel in aqueous acidic medium, Int. J. Electrochem. Sci., 2020, 15, 3283-3297. doi: 10.20964/2020.04.09

8. I. Abdulazeez, O.C.S. Al-Hamouz, M. Khaled and A.A. Al-Saadi, Inhibition of mild steel corrosion in $\mathrm{CO}_{2}$ and $\mathrm{H}_{2} \mathrm{~S}$-saturated acidic media by a new polyurea-based material, Mater. Corros., 2020, 71, no. 4, 646-662. doi: 10.1002/maco.201911270

9. F. Figueredo, R. Vera and A. Molinari, Evaluation of Eulychnia acida and Echinopsis chiloensis (Cactaceae) extracts in inhibiting corrosion of carbon steel in $\mathrm{HCl}$ solution, Mater. Corros., 2020, 71, no. 4, 663-673. doi: 10.1002/maco.201911274

10. D. Douche, H. Elmsellem, E.H. Anouar, L. Guo, B Hafez, B Tuzun, A.El Louzi, K. Bougrin, K. Karrouchi and B. Himmi, Anti-corrosion performance of 8hydroxyquinoline derivatives for mild steel in acidic medium: Gravimetric, electrochemical, DFT and molecular dynamics simulation investigations, J. Mol. Liq., 2020, 308, 113042. doi: 10.1016/j.molliq.2020.113042

11. I. Nadi, Z. Belattmania, B. Sabour, A. Reani, A. Sahibed-dine, C. Jama and F. Bentiss, Sargassum muticum extract based on alginate biopolymer as a new efficient biological corrosion inhibitor for carbon steel in hydrochloric acid pickling environment: Gravimetric, electrochemical and surface studies, Int. J. Biol. Macromol., 2019, 141, 137-149. doi: 10.1016/j.ijbiomac.2019.08.253 
12. R.F. Sadek, H.A. Farrag, S.M. Abdelsalam, ZMH Keiralla, A.I. Raafat and E. Araby, A powerful nanocomposite polymer prepared from metal oxide nanoparticles synthesized Via brown algae as anti-corrosion and anti-biofilm, Frontiers in Materials, 2019, 6, 1-17. doi: $10.3389 /$ fmats. 2019.00140

13. Oceanography and Marine Biology, Edition:1st Edition, 2015, Imprint CRC Press, 46.

14. A. Bazes, A. Silkina, P. Douzenel, F. Faÿ, N. Kervarec, D. Morin, J.P. Berge and N. Bourgougnon, Investigation of the antifouling constituents from the brown alga Sargassum muticum (Yendo) Fensholt, J. Appl. Phycol., 2009, 21, no. 4, 395-403. doi: 10.1007/s10811-008-9382-9

15. Yu.I. Kuznetsov, N.N. Andreev and S.S. Vesely, Why we reject papers with calculations of inhibitor adsorption based on data on protective effects, Int. J. Corros. Scale Inhib., 2015, 4, no. 2, 108. doi: 10.17675/2305-6894-2015-4-2-1

16. Yu. I. Kuznetsov, Organic corrosion inhibitors: where are we now? A review. Part I. Adsorption, Int. J. Corros. Scale Inhib., 2015, 4, no. 4, 284-310.

17. Yu.I. Kuznetsov, Current state of the theory of metal corrosion inhibition, Prot. Met., 2002, 38, 103-111. doi: 10.1023/A:1014904830050

18. Yu.I. Kuznetsov, Organic corrosion inhibitors: where are we now? A review. Part II. Passivation and the role of chemical structure of carboxylates, Int. J. Corros. Scale Inhib., 2016, 5, no. 4, 282-318. doi: 10.17675/2305-6894-2016-5-4-1

19. S. Rajendran, M. Agasta, R.B. Devi, B.S. Devi, K. Rajam and J. Jeyasundari, Corrosion inhibition by an aqueous extract of Henna leaves (Lawsonia Inermis L), Zast. Mater., 2009, 50, 77-84.

20. V. Sribharathy, S. Rajendran, P. Rengan and R. Nagalakshmi, Corrosion Inhibition By An Aqueous Extract Of Aleovera (L) Burm F. (Liliaceae), Eur. Chem. Bull., 2013, 2, 471-476.

21. N. Kavitha and P. Manjula, Corrosion Inhibition of Water Hyacinth Leaves, $\mathrm{Zn}^{2+}$ and TSC on Mild Steel in neutral aqueous medium, Int. J. Nano Corros. Sci. Engg., 2014, 1, 31-38.

22. J.A. Thangakani, S. Rajendran, J. Sathiabama, R.M. Joany, R.J. Rathish and S.S. Prabha, Inhibition of corrosion of carbon steel in aqueous solution containing low chloride ion by glycine - $\mathrm{Zn}^{2+}$ system, Int. J. Nano Corros. Sci. Engg., 2014, 1, 50-62.

23. S. Gowri, J. Sathiyabama, S. Rajendran and J.A. Thangakani, Tryptophan as corrosion inhibitor for carbon steel in sea water, J. Chem., Biol. Phys. Sci., 2012, 2, 2223-2231.

24. A.C.C. Mary, S. Rajendran, H. Al-Hashem, R.J. Rathish, T. Umasankareswari and J. Jeyasundari, Corrosion resistance of mild steel in simulated produced water in presence of sodium potassium tartrate, Int. J. Nano Corr. Sci. Engg., 2015, 1, 42-50.

25. T.A. Onat, D. Yiğit, H. Nazır, M. Güllü and G. Dönmez, Biocorrosion inhibition effect of 2-aminopyrimidine derivativeson SRB, Int. J. Corros. Scale Inhib., 2016, 5, no. 3, 273-281. doi: $\underline{\text { 10.17675/2305-6894-2016-5-3-7 }}$ 
26. V.I. Vigdorovich, L.E. Tsygankova, E.D. Tanygina, A.Yu. Tanygin and N.V. Shel, Preservativematerials based on vegetable oils for steel protection against atmospheric corrosion. I. Colza oil, Int. J. Corros. Scale Inhib., 2016, 5, no. 1, 59-65. doi: 10.17675/2305-6894-2016-5-1-5

27. P.N. Devi, J. Sathiyabama and S. Rajendran, Study of surface morphology and inhibition efficiency of mild steel in simulated concrete pore solution by lactic acid - $\mathrm{Zn}^{2+}$ system, Int. J. Corros. Scale Inhib., 2017, 6, no. 1, 18-31. doi: 10.17675/2305-6894-2017-6-1$\underline{2}$

28. L.G. Knyazeva, L.E. Tsygankova, A.V. Dorokhov and N.A. Kur'yato, Protective efficiency of oil compositions with Cortec VpCI-368D, Int. J. Corros. Scale Inhib., 2021, 10, no. 2, 551-561. doi: 10.17675/2305-6894-2021-10-2-4

29. M. Cenoui, I. Himer, R. Touir, M.E. Touhami, A. Dermaj, N. Hajjaji and H.El Kafssaoui, Synergistic influence of molybdate ions on the inhibition of corrosion and scale of ordinary steel in cooling water system by new organic compound, Zast. Mater., 2010, 51, 3-10.

30. N. Antony, H.B. Sherine and S.S. Rajendran, Investigation of the inhibiting effect of nano film by sodium meta silicate $-\mathrm{Zn}^{2+}$ system on the corrosion of carbon steel in neutral chloride solution, Zast. Mater., 2010, 51, 11-18.

31. S.S. Rajendran, T.S. Muthumegala, M. Pandiarajan, P.N. Devi, A. Krishnaveni, J. Jeyasundari, B.N. Samy and N.H. Beevi, Corrosion resistance of SS316L in simulated concrete pore solution in presence of trisodium citrate, Zast. Mater., 2011, 52, no. 2, $85-89$.

32. A.S. Fouda, G.Y. Elewady, A. EL-Askalany and K. Shalabi, Inhibition of aluminum corrosion in hydrochloric acid media by three Schiff base compounds, Zast. Mater., 2010, 51, no. 4, 205-219.

33. S. Rajendran, V. Sribharathy, A. Krishnaveni, J. Jeyasundari, J. Sathiyabama, T.S. Muthumegala and M. Manivannan, Inhibition effect of self assembled films formed by adipic acid molecules on carbon steel surface, Zast. Mater., 2011, 52, no. 3, 163-172.

34. M. Dahmani, A. Et-Touhami, S.S. Al-Deyab, B. Hammouti and A. Bouyanzer, Corrosion Inhibition of C38 Steel in $1 \mathrm{M} \mathrm{HCl}$ : A Comparative Study of Black Pepper Extract and Its Isolated Piperine, Int. J. Electrochem. Sci., 2010, 5, 1060-1069.

35. I.B. Obot, S.A. Umoren and N.O. Obi-Egbedi, Corrosion inhibition and adsorption behaviour for aluminuim by extract of Aningeria robusta in $\mathrm{HCl}$ solution: Synergistic effect of iodide ions, J. Mater. Environ. Sci., 2011, 2, 60-71.

36. D. Bouknana, B. Hammouti, M. Messali, A. Aouniti and M. Sbaa, Phenolic and nonPhenolic Fractions of the Olive Oil Mill Wastewaters as Corrosion Inhibitor for Steel in HCl, Port. Electrochim. Acta, 2014, 32, 1-19. doi: 10.4152/pea.201401001 